\title{
Financial Vulnerability in Asia
}

\author{
Stephany Griffith-Jones and Ricardo Gottschalk*
}

\begin{abstract}
1 Introduction
Currently, much of Asia is growing at a very impressive rate, with the Bank for International Settlements (BIS 2005a) reporting growth for the whole region of 7.8 per cent in 2004 and estimating growth of 7.2 per cent in 2005. This is allowing for a very significant reduction in poverty. Continued high growth is crucial from a perspective of poverty reduction, as the number of poor people in Asia remains very large and they comprise a high proportion of the world's poor. Also, though most Asian countries have very dynamic growth, there are several exceptions.
\end{abstract}

One of the potential important risks that could undermine continued growth and poverty reduction in Asia is a financial crisis, especially if it spread through contagion from one country to another and/or if it occurred in a major country. The financial and development costs of the 1997/8 East Asian crisis were massive.

The current prospects for a new financial crisis appear to be low for most of Asia. Many countries in the region have very strong macroeconomic fundamentals, and policy makers are actively seeking to continue making progress in overcoming potential remaining sources of vulnerability, e.g. in the banking sector. They have also built very strong defences for preventing future currency crises in the form of extremely high foreign exchange reserves. However, important weaknesses do remain while new challenges are being added, linked for example to the liberalisation of the domestic financial sectors, opening up to foreign banks, growth of the derivatives markets and possible further liberalisation of the capital account. Furthermore, new shocks can come either from within Asian countries (e.g. political instability) or from the international economy (e.g. a rapid slowdown of the global economy).
To summarise, as Asian policy makers learned only too well, the negative impacts of crisis on growth and poverty reduction are horrendous. Therefore, it is very important to minimise the risk of crises occurring as much as possible. It is often during good times, when excessive risks can be assumed, that future crises are hatched. However, during good times it is also easiest to take measures to reduce the likelihood of future crises.

In this article, we will first estimate the total losses in output caused by the East Asian crisis. We will then look at sources of strength and vulnerability in Asian economies. We will focus much more on China, not necessarily because it is more vulnerable to crisis, but because its scale and dynamism makes it so important for the rest of the region (and the world). China is also the focus because it is and will be undergoing important changes, such as the opening up of the banking system to foreign banks under World Trade Organization (WTO) commitments. However, references will also be made to other Asian countries. The final section will outline some of the key policy issues for reducing the likelihood of financial crises.

This article focuses on the need to reduce financial vulnerability to avoid costly crises that can be so damaging to growth and poverty reduction. Clearly there are other equally or more important issues for poverty reduction that escape the scope of this article. These relate to how in 'normal times' the financial sector can contribute more to 'pro-poor' growth.

A major challenge is to improve access to formal financial services for vast categories of the population who are currently either totally excluded or have very limited access to such services, so as to generate employment and increase income. This is particularly important in rural areas (IFAD 2001), for the informal sector, for small and medium 


\section{Box 1 Methodological approach for calculating output loss}

Output loss caused by financial crises can be measured in a variety of ways. First, one can quantify the loss of output incurred during the crisis period. Alternatively, one can measure the cumulative output loss that occurs over time due to a lower output level or trend during and after a crisis episode. Cumulative output loss, in turn, can be measured either by summing up the annual difference between potential growth rates and observed growth rates, or by summing up the differences in output levels (Hoggarth and Saporta 2001). Previous studies have attempted to estimate cumulative output loss resulting from financial crises by looking at the difference between growth rates (e.g. IMF 1998; Aziz et al. 2000). However, Hoggarth and Saporta (2001) correctly point out that measuring the difference in output levels rather than growth rates leads to a better estimate of the actual loss of output incurred. Accordingly, they suggest a methodological approach for the former type of measurement.

We estimate cumulative output loss by measuring the difference in output levels, thus adopting a methodological approach similar, although not exactly the same, as that suggested by Hoggarth and Saporta (2001). Specifically, we measure the cumulative difference between projected potential output and actual output over the years, starting from the first crisis year. Potential output is represented by the country's output trend in the years preceding a major crisis episode. The period upon which the output trend is based is 1991-6 - six years in total (other studies calculate their trends over a shorter pre-crisis period, between three and five years; see Hoggarth and Saporta 2001). The use of a six-year period is intended to reduce the possibility of overestimating the output trend in those cases where growth accelerates in the years immediately preceding the crisis episode. The output trend corresponds to the fitted values of a linear regression of the real GDP level variable regressed on a time trend plus a constant. All estimated trends have a high degree of fitness.

enterprises (SMEs) and for young entrepreneurs. $A$ three-pronged approach is required. First, incentives may need to be provided and regulations may need to be modified to encourage banks to expand their activities towards these customers. This is a complex task. A concrete example is the need to adapt the implementation of Basle II banking regulations within Asian economies, so they do not introduce further biases against lending to SMEs (see Gottschalk 2005). For the former, credit guarantee schemes can be effective in promoting changes in bank lending behaviour if: (a) specific factors for success exist - such as an open, competitive banking environment (DFID 2005) and (b) the guarantee schemes are well designed so they do not, for example, imply excessive contingent liabilities for governments or donors, or cover the totality of the risk (Griffith-Jones and Fuzzo de Lima 2006).

Second, microfinance institutions can play a useful complementary role in providing access to credit for very small entrepreneurs (for a recent comprehensive review, see Helms and CGAP 2006; for a very good earlier discussion, see Hulme and Mosley 1997). Asia has a rich and pioneering experience in such microfinance institutions that can be further developed, for example, by a more supportive regulatory framework.

Third, where there are clear cases of market failure or temporary gaps, there may be a case for public intervention. Examples of relevant market failures to be addressed are information asymmetries, high initial transaction costs of lending to SMEs and/or the need to develop financial expertise by the small or microbusinesses. These interventions are perhaps most effective when they are time-limited and are linked to institutional developments that can then be implemented in a sustainable way by the private financial sector. For example, government or donor intervention can facilitate microfinance institutions to grow and this can ideally attract banks into microfinance. Such interventions can also take place through private-public partnerships, especially to finance infrastructure that in certain sectors can provide an important expansion of services for the poor.

\section{Costs of crises}

The costs of excessive financial instability leading to crises are massive. $A$ key cost is forgone output. Here we estimate the output loss of the four Asian countries hardest hit by the financial crisis of 1997; 
Table 1 Cumulative output loss for each crisis country*

\begin{tabular}{lll}
\hline & US\$ billion & As a proportion of 2002 GDP (\%) \\
\hline Indonesia & 345.9 & 133 \\
Korea & 178.1 & 26 \\
Malaysia & 87.8 & 69 \\
Thailand & 305.2 & 157 \\
Total & $\mathbf{9 1 7 . 0}$ & $\mathbf{7 2}$ \\
\hline
\end{tabular}

*Cumulative output loss over the 1997-2002 period.

Author's elaboration, based on World Bank database.

Indonesia, Korea, Malaysia and Thailand. Just for these countries for the 1997-2002 period, we estimate a total output loss of US\$917 billion, which is an annual average of around US\$150 billion for that period.

Table 1 shows output losses for each of the four countries under consideration. It shows that the largest losses were incurred by Indonesia, and the smallest by Malaysia. However, these are losses in absolute terms, thus not adjusted by the gross domestic product (GDP) sizes of their economies. The cumulative output loss corresponds to 72 per cent of the combined GDPs of the four countries for the year 2002, and to 40 per cent of East Asia's total GDP for the same year.

The output losses reflect lower growth rates during and after the crisis in each of these countries (see
Box 1 for methodological explanation). Table 2 shows that while average growth before the Asian crisis was at 7.3 per cent for Korea, around 8 per cent for Indonesia and Thailand, and 9.6 per cent for Malaysia, average growth over the 1997-2002 period was 4.5 per cent in Korea and 0.5 per cent in Indonesia.

Of course, the poorer economic performance observed among these countries after the crisis episode may not be attributed to the crisis alone. But it is clearly the consensus that the crisis was the preponderant factor behind it.

The biggest estimated absolute loss has been incurred by Indonesia - of US\$346 billion, where actual output has remained far below its potential level for several years, as clearly illustrated by Figure 1 .

\section{Figure 1 Indonesia: potential and actual GDP}

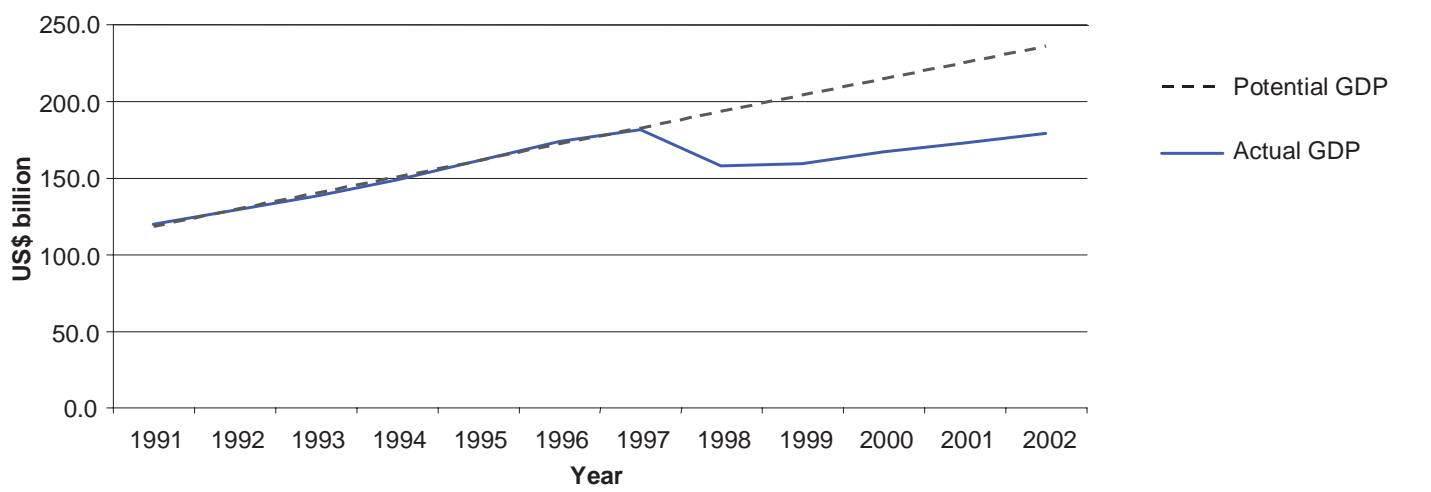

Projected output for the years 1997-2002 based on output trend over the 1991-6 period. Values are in US\$1989, billion

World Bank database. 


\begin{tabular}{|c|c|c|c|c|c|c|c|c|}
\hline \\
\hline \multicolumn{9}{|c|}{ 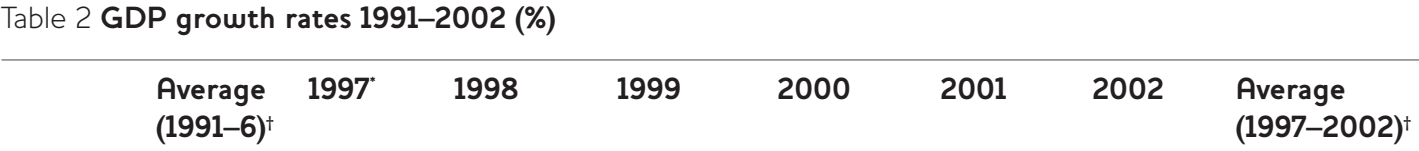 } \\
\hline Indonesia & 7.8 & 4.7 & -13.1 & 0.8 & 4.9 & 3.4 & 3.7 & 0.5 \\
\hline Korea & 7.3 & 5.0 & -6.7 & 10.9 & 9.3 & 3.1 & 6.4 & 4.5 \\
\hline Malaysia & 9.6 & 7.3 & -7.4 & 6.2 & 8.5 & 0.3 & 4.1 & 3.0 \\
\hline Thailand & 8.2 & -1.4 & -10.5 & 4.5 & 4.8 & 2.2 & 5.4 & 0.7 \\
\hline
\end{tabular}

*Crisis year: Indonesia (July 1997); Korea (October 1997); Malaysia (September 1997); Thailand (July 1997). +Geometric average.

Author's elaboration, based on World Bank database.

The full magnitude of the output loss was massive. Indonesia experienced larger falls in output and incomes during and after its crisis than that of the USA in the Great Depression. As important, it is estimated that the poverty headcount in Indonesia doubled following the crisis: from 7-8 per cent in 1997 to 18-20 per cent in 1998 (Suryahadi et al. 2000).

The other Asian countries also witnessed major output loss, mainly because (as was the case with Indonesia) actual output by 2002 had not returned to its potential level. This is the case even in Korea, where economic recovery among all crisis-affected countries has been the most robust, see Figure 2 .

These estimates suggest that for 1997-2002, the annual cost of the Asian crisis reached US $\$ 150$ billion (in 2002 US\$). Such an estimate of the direct costs of crises may seem rather high, but the order of magnitude is similar to other estimates. See, for example, Eichengreen (2004), who estimates that over the last quarter of a century, currency and banking crises have reduced incomes of developing countries by around 25 per cent.

The estimate in Table 1 of US\$917 billion for the 1997-2002 period may, in fact, underestimate total costs associated with financial crises, as they do not take account of either lower economic growth in other Asian countries due to contagion effects via the financial channel (e.g. Hong Kong, the Philippines), or lower growth induced via the trade channel, due, for example, to lower prices of exports and declines in volumes of exports.

\section{Figure 2 Korea: potential and actual GDP}

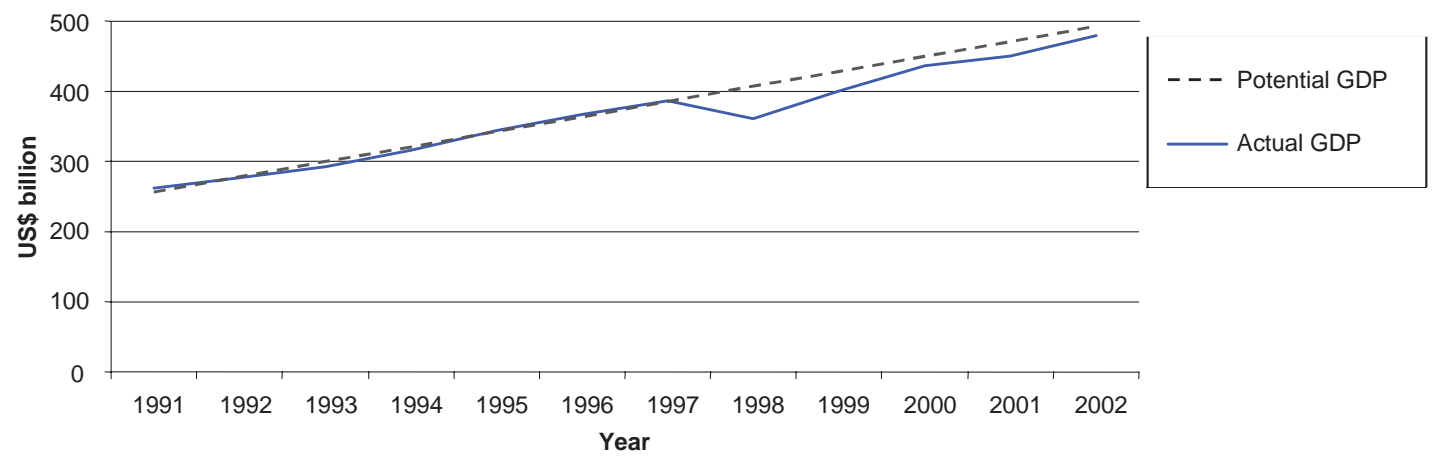

Projected output for the years 1997-2002 based on output trend over the 1991-6 period. Values are in US\$1989, billion.

Data source World Bank database. 
Table 3 Macroeconomic indicators

\begin{tabular}{|c|c|c|c|c|c|c|c|c|c|c|c|c|}
\hline & \multicolumn{2}{|c|}{$\begin{array}{l}\text { Real GDP } \\
\text { growth (\%) }\end{array}$} & \multicolumn{3}{|c|}{$\begin{array}{l}\text { Foreign exchange } \\
\text { reserves excluding } \\
\text { gold (US } \$ \text { billion) }\end{array}$} & \multicolumn{3}{|c|}{$\begin{array}{l}\text { Total external } \\
\text { debt (US\$ billion) }\end{array}$} & \multicolumn{4}{|c|}{$\begin{array}{l}\text { Debt-service } \\
\text { ratio, paid (\%) }\end{array}$} \\
\hline & 03 & 04 & 05 & 03 & 04 & 05 & 03 & 04 & 05 & 03 & 04 & 05 \\
\hline China & 9.3 & 9.5 & * & 408.2 & 614.5 & $*$ & 193.6 & 229.6 & $*$ & 7.3 & 6.2 & $*$ \\
\hline India & 8.6 & 6.9 & * & 98.9 & 126.6 & * & 113.5 & 118.6 & * & 19.6 & 10.7 & * \\
\hline South Korea & 3.1 & 4.7 & 3.4 & 155.3 & 199.0 & 220.0 & 132.8 & 144.7 & 153.9 & 6.3 & 5.5 & 5.6 \\
\hline Thailand & 6.9 & 6.1 & 4.0 & 41.1 & 48.7 & 50.3 & 51.8 & 50.8 & 49.4 & 15.3 & 9.7 & 10.3 \\
\hline Indonesia & 4.9 & 5.1 & 5.0 & 35.0 & 35.0 & 33.7 & 134.4 & 137.4 & 140.5 & 25.6 & 16.3 & 12.3 \\
\hline Philippines & 4.5 & 6.0 & 5.0 & 13.7 & 13.1 & 15.6 & 62.7 & 65.8 & 66.3 & 20.6 & 15.6 & 16.4 \\
\hline
\end{tabular}

*No available data.

Economist Intelligence Unit (2005).

\section{Sources of strength and weakness}

3.1 Sources of strength - but with some caveats

There are many sources of strength and dynamism in most of the East and South Asian economies, several of which are summarised in Table 3.

\section{Rapid growth}

Overall, the Asian economies are strong, displaying rapid economic growth, great dynamism of exports, large trade surpluses and very high savings rates. This is not only true for both China and India, but also for most countries in East and South Asia. But this, in itself, is no guarantee that financial crises will be avoided in the future. The countries affected by the Asian financial crisis in 1997 also had very high growth rates, as well as very high savings rates. This was an important and disturbing feature of the 1997 crisis compared with most previous financial crises in developing countries.

In looking to the future, a key question is whether such dynamism can be maintained, or whether any slowdown of growth can be gradual and managed. The extent to which growth depends not just on external demand, but also on domestic demand, would provide a potential source for stability of growth; the latter is an issue that is increasingly being discussed by policy makers in countries like China.

In the rest of Asia, domestic demand has played a much greater role recently than it did in the past, which is positive from this perspective (BIS 2005a).
The sustainability of domestic demand could be helped by the fact that it was accompanied by measures to boost private sector investment. For example, in Korea, corporate restructuring has implied that the debt/equity ratio in manufacturing fell from around 400 per cent in 1997 to about 100 per cent in March 2004. In India, strong corporate earnings underpin investment. The growth of bank lending to households has also supported increased domestic consumption (and can continue to do so).

\section{High levels of reserves}

The second source of strength in preventing currency crises is the extremely high levels of foreign exchange reserves (see again Table 3). Indeed, at the end of 2004, the total combined reserves of China, Taiwan, Korea and India reached US\$1.2 trillion, which represents over 30 per cent of the world's foreign exchange reserves. It is noteworthy that over US $\$ 300$ billion of those reserves were accumulated in 2004, as the pace of reserve accumulation had built up since 2001 (Genberg et al. 2005).

Indeed, except for Indonesia and the Philippines, for the countries listed in Table 3 (China, India, Thailand and South Korea) foreign exchange reserves, excluding gold, are much larger than total external debt. Foreign exchange reserves are therefore - for those countries - much larger than short-term debt, whose non-renewal is most likely to be problematic in provoking currency crises (Rodrik and Velasco 1999). 


\section{Box 2 The cost of holding foreign exchange reserves}

In many developing countries, holding high levels of foreign exchange reserves and sterilising them does have quite significant costs, estimated for example at around 1 per cent of GDP in the first half of the 1990s in several major Latin American countries (see Ffrench-Davis and Griffith-Jones 1994). Genberg et al. (2005) estimate that for early 2004, the cost of sterilisation of reserves per year for Korea and for India reached 0.5 per cent of GDP. This financial cost is due to the fact that reserves are usually held in low-yielding US Treasury bills, whereas the bonds issued locally (to compensate for the monetary impact) have higher costs.

However, for Taiwan, Singapore, China, Malaysia and Thailand, short-term interest rates are actually below or at US levels, implying that the cost of sterilisation is either extremely low or even negative. However, if these currencies are revalued in the future, the accumulated foreign reserves could imply a significant fiscal loss (Zhang 2005).

For China, Prasad and Wei (2005) estimate that reserve holdings were ten times the level of shortterm debt, a much higher ratio than for other developing countries. ${ }^{2}$ This is very reassuring. It should be mentioned that the composition of capital inflows has recently taken a less positive trend. Though a large proportion of inflows into China take the form of foreign direct investment (FDI) (and thus are probably more stable), about $30-40$ per cent of the increase in the foreign exchange reserves in the past three years is linked to 'speculative' capital inflows. These were estimated to reach around US\$120-160 billion from 2002-4 (Zhang 2005). ${ }^{3}$ These speculative or 'hot money' inflows would seem to be chasing an expected revaluation in the renminbi. Increases of reserves originating in 'hot money' inflows are significantly less healthy than those originating in trade surpluses and FDI, as has occurred in the past in China and in other Asian economies. It has been argued that the scale of 'hot money' inflows would have been even larger had there been no capital controls. Therefore, these should not be lifted. Furthermore, some Chinese scholars (e.g. Zhang 2005) have argued persuasively that the existence of such large inflows of 'hot money' could even justify temporarily strengthening capital controls on inflows rather than liberalising them. Some variation on the Chilean unremunerated reserve requirements (VRR or encaje) could be an interesting option. The Chilean encaje, imposed in times of surges (especially of shortterm capital), required a part of the inflow to be deposited in the Central Bank, without remunerations. This lowered the yield, and thus the attractiveness of bringing money into Chile. As it was applied only during the first year, it particularly discouraged short-term inflows.

It is reassuring that Chinese reserves at the end of 2004 reached 53 weeks of imports that year, again well above practically every other developing country. There are, however, two aspects that make China's massive reserves look less excessive.

\section{Table 4 Total 2004 capital adequacy in Asia Pacific (\%)}

$\begin{array}{lr}\text { Thailand } & 12.6 \\ \text { Indonesia } & 19.4 \\ \text { Hong Kong } & 15.4 \\ \text { Philippines } & 18.6 \\ \text { Malaysia } & 14.2 \\ \text { Taiwan } & 10.7 \\ \text { Korea } & 12.1 \\ \text { Singapore } & 16.3\end{array}$

Moody's (2005a), based on bank regulators in each country. 
One is the reserve coverage of the monetary base (defined as M2), which for China covers only about 20 per cent of M2. Should China fully liberalise its capital account in the future (which we consider both unlikely and undesirable in the short to medium term) and become vulnerable to capital flight or - more gradually - outflows by domestic and foreign investors, the current level of reserves does not seem so excessive. More relevant in the current context, an additional reason given for high levels of reserves (e.g. by Prasad and Wei 2005) is the need to help cushion the banking sector from shocks. If non-performing loans of the banks are around 14 per cent of GDP in China, this is a large proportion of total foreign exchange reserves. Though it seems unlikely that even a very large banking crisis (which is improbable) would require such a massive recapitalisation, these comparisons give some logic (in terms of 'self-insurance') to such extremely large levels of foreign exchange reserves.

Holding such high levels of reserves, with the aim of 'self-insurance' in China and, to a lesser extent, in other Asian countries, implies significant costs which are onerous for developing countries, especially the poorest ones. It would be far more efficient if there were complementary mechanisms for 'collective insurance'. These could either be provided by the international community, for example, via issuing Special Drawing Rights (SDRs) (Griffith-Jones and Ocampo 2003) or creating an International Monetary Fund (IMF) facility for helping stop capitalaccount crises (Cordella and Yeyati 2005), or through regional mechanisms, such as building on the Chiang-Mai Asian Initiative.

Before looking at the costs of holding such large reserves, it is important to emphasise that 'selfinsurance' against crisis is not the only reason why Asian countries hold such high levels of reserves. In several cases, the wish to avoid excessive strengthening of their currencies, which would undermine competitiveness of their exports, is also a very important factor.

To summarise, except for one or two of the countries analysed, external vulnerability to crisis is significantly lowered by extremely high reserves. This could be particularly valuable if the international cycle turns, credit spreads increase and terms of trade deteriorate.

\section{Strong fiscal situation and low inflation}

Most Asian countries have relatively manageable fiscal deficits to GDP; furthermore, average fiscal deficits have been declining since 2001, when many countries gave fiscal stimulus to boost domestic demand. Nevertheless, fiscal deficits remain large in India (where they have been above 9 per cent of GDP in the 2002-4 period) and in the Philippines.

Inflation in the Asian countries analysed remains fairly low, and inflation volatility has decreased in most cases. Low inflation should give central banks more flexibility in responding to external shocks. It also tends to reduce risk premia for external borrowing.

\subsection{Potential sources of weakness}

\section{The banking sector}

As learned only too well in East Asia and elsewhere, weak financial systems can either cause or deeply accentuate crises originating in other causes. Asian policy makers are aware of these risks and have taken measures to reduce vulnerabilities, but important challenges remain.

In Asia - more than elsewhere - economic and systemic risks tend to be highly concentrated in the banking sector, as capital markets are relatively underdeveloped. This is particularly the case in China, where the corporate bond market is very underdeveloped, accounting for only 1 per cent of corporate financing in 2004 (Moody's 2005b). As a result, long-term capital needs are often funded by short-term bank lending, increasing liquidity and interest risk in banks. As a consequence, one important (albeit indirect) way of reducing vulnerability of the banking system is to develop and deepen local capital markets - not necessarily an easy task. In particular, reform of China's capital markets has faced difficulties, which have implied that the stock market has been falling for several years, even though the economy is so dynamic.

In recent years, there has been quite a significant and broad-based improvement in Asian banking. The following points summarise the overall situation outside of China.

- Bank profitability has tended to rise, especially in 2004. To an important extent, this can be explained in countries like India by cyclical factors, such as strong growth and declining long-term interest rates (BIS 2005a; Sen 2005). In Korea, 
bank earnings have increased significantly, as earlier problems with household credit (creditcard related) eased.

- Overall, capital adequacy has also been improving in Asia. For most major Asian countries (except China), capital adequacy ratios are high, and well above the 8 per cent minimum Basle ratio (Table 4), thus providing an important buffer against shocks to the banking systems. Naturally, capital adequacy measurements are never precise, and are also subject to cyclical fluctuations.

- Non-performing loans (NPLs) have been reduced in many East and South Asian countries, although high NPLs remain an issue in the Philippines and Thailand, as well as in China.

- Improvements in Asian banks' performance indicators have led to significant recent credit ratings upgrades (see Moody's 2005a). However, as the BIS (2005a) rightly points out, this partly reflects cyclical factors, which may be temporary. Indeed, policy makers need to treat international rating agencies' evaluations with some caution, as they are often very pro-cyclical, and as their ratings were quite problematic before and during the Asian crisis.

In spite of this performance, some remaining areas of risk can be highlighted. The first is linked to increased lending to consumers, regarded by banks (especially foreign ones) as profitable and safe. If this credit expands too quickly, and especially if economies later slow down, this can lead to banking problems. For example, credit card debt has begun to expand rapidly in several Asian economies, and non-payments created significant problems in Korea, which are now being overcome. Mortgage loans are apparently safer due to the collateral provided by houses; however, rapid property price rises pose the risk of reversal of prices, which can lead to increased losses in mortgage lending. Negative wealth effects of property price falls can depress total aggregate demand and lead to further bank losses.

The measures taken by several Asian governments (e.g. in Korea, China and Thailand) to dampen property price increases are therefore well taken. Similarly, the spreading of credit bureaus in Asia is helpful for accessing borrowers' credit worthiness.

A second area of risk for banking systems is currency mismatches (BIS 2005a). Especially in Asia, currency mismatches have fallen sharply at the national level, as foreign currency debt fell in proportion to exports and reserves. However, in some Asian countries, private sector foreign currency mismatches are large; such mismatches could pose risks to the banks if sharp changes in exchange rates occurred.

More generally, as the Bank for International Settlements (BIS 2005b) points out, 'foreign ownership exposes local banking systems more directly to changes in global conditions'. Indeed, as the study points out, changes in risk appetite or in business strategy at the parent level can affect the level of resources allocated to a specific country by the foreign bank, including the possibility of total exit from the country in bad times. This could be very negative if foreign banks constitute a high proportion of the total banking system. Furthermore, regulatory decision making may migrate excessively to home countries, leaving local supervisors insufficiently informed of potential risks and with insufficient power to influence subsidiaries and branches of foreign banks.

Third, the rising exposure of banks to government bonds can lead to associated market risk. If longterm interest rates rise, banks can have significant losses. This could be particularly important in India as the value of these bonds fall.

\section{The banking system in China}

One country in Asia where the banking system remains somewhat fragile is China. It is very positive that the government has made accelerated efforts to strengthen the banking system, particularly by recapitalising the state banks, but also by slowing down excessive growth of bank lending, which has reduced systemic risk. However, as discussed below, several fragilities remain and new challenges are opening up, so it seems desirable that policy makers proceed cautiously with domestic financial liberalisation and capital account liberalisation, especially till the banking system is strengthened.

China's banking system is, by most measures, large (especially when compared with other developing countries). For example, its ratio of credit to GDP is almost double that of the average for Asian emerging markets (Prasad et al. 2005). Despite the problems and limitations discussed below, it has played a very positive role in supporting Chinese economic growth. This makes the banking system central to the Chinese economy, and any serious disruption to it - and worse still a crisis - particularly problematic. 
Chinese banks' balance sheets shortcomings are reflected in fairly low profitability by international standards: after-tax returns for the large banks were reported at only 0.4 per cent in 2003 (Moody's 2005a). Good profitability offers a cushion against adverse economic downturns and asset quality deterioration. Without such a cushion, Chinese banks are more vulnerable to external and internal shocks. Furthermore, the Chinese banking system has a combination of high NPLs, low capital adequacy ratios (CARs) and low provisioning. These are interrelated, as large NPLs create a need for increased provisioning, which reduces profitability and puts downwards pressure on CARs.

There has been significant progress in reducing Chinese banks' reported NPL ratios, but they still remain high. Moody's (2005b) estimates them at over 13 per cent of GDP for 2005, significantly lower than for 2002. However, they are estimated to be the highest in Asia with the Philippines (13 per cent) and Thailand (12 per cent) reportedly following close behind, while Malaysia (7.5 per cent), Indonesia (5.8 per cent) and Korea (1.6 per cent) have significantly lower ratios. These figures may be an underestimate of the true position. NPLs are difficult to estimate and are often understated. For example, some so-called 'evergreen' loans are difficult to detect, as loan officers keep rolling them out to keep the loan classed as 'performing', even though the lender knows the principal is at significant risk.

Furthermore, Chinese banks are inadequately capitalised. Though no official data seem to be reported for the banking system as a whole, in 2003 most Chinese banks had CARs below the Basle international minimum of 8 per cent. Also, if compared with other Asian countries (see Table 4), Chinese CARs are much lower. The large state banks have seen their capital levels improve, thanks to large recapitalisations by the government, and increasingly by Initial Public Offerings (IPOs). Smaller banks, however, are in a much more difficult situation. The declining stock market makes it difficult for them to issue equity.

A key source of support for the Chinese banking system has been recapitalisation by the government. Moody's (2005b) estimates total public support till now - via both the Ministry of Finance and the Central Bank (People's Bank of China) - at a staggering US\$259 billion (other sources have lower estimates). It is widely expected that very strong government support will continue even when banks are privatised. Though very costly, this support is extremely valuable to compensate for weaknesses in Chinese banks.

As regards the future, the profitability of Chinese banks could increase as banks diversify their lending even more, for example, into loans to consumers or fee-generating business such as wealth management. However, loans to consumers also pose new risks; for example, if a real estate bubble materialised, this could add significant risks to Chinese banks. The fact that China still has no centralised credit bureau, except in Shanghai, could exacerbate risks from mortgage lending though the proposed establishment of such a bureau will be valuable.

There may be difficult trade-offs for the Chinese authorities. Some of the measures to increase bank profitability may imply, for example, closing branches in remote rural regions, which may actually reduce access to financial services for very poor people. It is important that the necessary increase in bank profitability is achieved in ways that do not harm the poor, or that compensatory measures are taken to protect them.

Perhaps the main risk for Chinese banks would be a sharp reduction (or downturn) in Chinese economic growth. At the moment, this seems very unlikely, but in the longer term it is a concern that needs to be taken account of. Decisions on capital account liberalisation and on changes in exchange rate regimes need to be extremely careful and gradual, so as to avoid adding new sources of volatility and risk on a still fragile banking system.

More immediately, planned liberalisation of interest rates (especially of deposit rates) could damage profitability of some banks. Therefore, it seems important that such deregulation is carried out gradually, as very rapid elimination of low deposit rates could seriously impact already low profits.

Another immediate challenge for Chinese banks is that - according to its WTO commitments - the country will fully open its banking sector at the end of 2006. This will have positive effects (such as increases in efficiency and more modern risk management). However, competition from foreign banks could put additional pressure on still relatively 
weak Chinese banks, especially if domestic banks are left with less creditworthy firms, as the most creditworthy ones become clients of foreign banks. Increased foreign participation, however, seems to be likely to be gradual and partial. This could also limit the risk of liquidity problems in domestic banks, should Chinese depositors shift their money into foreign banks, for example, due to safety concerns. This could pose threats to Chinese banks in the medium to long term.

\section{Policy priorities}

Overall, Asian growth has been very dynamic for a long time. This has enabled the levels of poverty reduction unseen in other parts of the world. The extent of poverty reduction in Asia is absolutely unique in history. This gives rise to a first and general line of advice. In areas where Asian economies are (and have been) strong, they should build on those strengths. When there is a contradiction between national perceptions based on accumulated experience and foreign advice, it would seem better to give greater weight to national ideas, especially those not influenced by vested interests.

At this broad level, it also seems reasonable to be prudent in introducing changes, and to do so gradually. The area of liberalisation of the capital account seems to be a good example, especially for successful countries with weak banking systems like China. Any benefits, in terms of attracting additional capital (which is much less necessary given high domestic savings rates) or providing more depth, liquidity and expertise to the domestic capital market, need to be carefully weighed against possible increased costs and risks. In particular, the risks of financial and currency crises must be minimised. Indeed, in a recent speech (26 October 2005) at the Seventh Meeting of the Institute of International Finance (IIF)'s Asian CEO Summit, Deputy Governor of the Chinese Central Bank, Xiang Jumbo, stressed that as 'global financial

\section{Notes}

* Ricardo Gottschalk wrote the second section, and Stephany Griffith-Jones wrote the rest of the article. We thank Piero Calice and Edward Griffith-Jones for valuable assistance.

1 However, an excessive expansion of household credits could pose risks, as discussed later.

2 The BIS, based on official Chinese data, estimates that Chinese reserves amount to six times the integration is strengthened, cross-border contagion effects of financial risks will be increased as well'.

On the specific issue of capital account liberalisation, it is interesting to note that there is wide support for great prudence for China. Thus, the head of the China Division at the IMF said in 2004 that 'given the weaknesses in the financial sector, I think that maintaining capital controls or even selectively tightening them may be very important in terms of protecting the weak financial sector from external pressures ...' (Prasad 2004).

As regards domestic financial liberalisation, again prudence seems necessary, especially in relation to weak banking sectors. One priority area for action is the development of domestic capital markets, especially domestic bond markets. When modifying financial systems and adapting them to the needs of more market-orientated economies, it is also important to preserve features that have been positive, such as support for corporate investment and growth (provided those corporations are efficient). It also seems crucial to strengthen regulation and supervision.

An important way of preventing crises is to constantly follow prudent macroeconomic policies. This has typically been the case in East and South Asia, and it has served the region well. But where fiscal deficits (e.g. India) and/or external debt service ratios (e.g. the Philippines) are too high, it seems important to implement measures to reduce them. However much is done to be prudent and to build defences, there will always be the risk of crises - or even of large slowdowns - in all economies. As a consequence, establishing good social safety nets seems a useful precaution.

Finally, strengthening regional and multilateral mechanisms for crisis prevention and better management remains a priority (see, for example, WESS 2005).

level of short-term external debt, still above comparable data for other countries.

3 Prasad and Wei (2005) assume an even higher ratio for 2003. Other sources, e.g. Genberg et al. (2005), have lower estimates for 'hot money' inflows into China - a new phenomenon that is difficult to measure. 


\section{References}

Aziz, J., Caramazza, F. and Salgado, R. (2000) Currency Crises: In Search of Common Elements, IMF Working Paper 00/67, Washington DC: International Monetary Fund

BIS (2005a) 75th Annual Report, Basel: Bank for International Settlements

BIS (2005b) Quarterly Review, Basel: Bank for International Settlements, December

Cordella, T. and Yeyati, E.L (2005) A (New) Country Insurance Facility, IMF Working Paper 05/23, Washington DC: International Monetary Fund

DFID (2005) Do Credit Guarantees Lead to Improved Access to Financial Services?, DFID Working Paper, London: Department for International Development

Economist Intelligence Unit (2005) Macroeconomic Indicators, London: Economist Intelligence Unit

Eichengreen, B. (2004) 'Financial Instability', paper written on behalf of the Copenhagen Consensus, May

Ffrench-Davis, R. and Griffith-Jones, S. (1994) Coping with Capital Surges: The Return of Finance to Latin America, Boulder, CO: Lynne Rienner Publishers

Genberg, H., McCauley, R., Park, Y.C. and Persaud, A. (2005) Official Reserves and Currency Management in Asia: Myth, Reality and the Future, Geneva Reports on the World Economy 7, Geneva: International Center for Monetary and Banking Studies

Gottschalk, R. (2005) International Codes and Standards and Development Finance, Report to Department for International Development (DFID)

Griffith-Jones, S. and Fuzzo de Lima, A.T. (2006) 'Mitigating the Risks of Investing in Developing Countries; Currency-Related Guarantee Instruments for Infrastructure', in Inge Kaul and Pedro Conceicao (eds) The New Public Finance: Responding to Global Challenges, New York: Oxford University Press

Griffith-Jones, S. and Ocampo, J.A. (2003) 'What Progress on International Financial Reform? Why So Limited?', paper prepared for the Expert Group on Development Issues (EGDI), Stockholm

Helms, B. and CGAP (Consultative Group to Assist the Poorest) (2006) Access for All: Building Inclusive Financial Systems, Washington DC: World Bank

Hoggarth, G. and Saporta, V. (2001) 'Costs of Banking System Instability: Some Empirical
Evidence', Financial Stability Review, Bank of

England, June

Hulme, D. and Mosley, P. (1997) 'Finance for the Poor or the Poorest? Financial Innovation, Poverty and Vulnerability', in G.D. Wood and I. Sharif (eds) Who Needs Credit? Poverty and Finance in Bangladesh, Dhaka: University Press Ltd and London: Zed Books

IFAD (2001) Rural Poverty, Rome: International Fund for Agricultural Development

IMF (International Monetary Fund) (1998) 'Financial Crises: Characteristics and Indicators of Vulnerability', World Economic Outlook, October

Moody's (2005a) 'Asia Banking Outlook', Moody's Special Comment, July

Moody's (2005b) 'China - Reforms on Track, But More Needed', Moody's Banking System Outlook, June

Prasad, E. (2004) 'Growth and Stability in China: Prospects and Challenges', Harvard China Review Annual Conference, Cambridge, MA, www.imf.org/external/np/speeches/ 2004/041704.htm (accessed December 2005)

Prasad, E., Rumbaugh, T. and Wang, Q. (2005) Putting the Cart Before the Horse? Capital Account Liberalization and Exchange Rate Flexibility in China, IMF Policy Discussion Paper 05/1, Washington DC: International Monetary Fund

Prasad, E. and Wei, S.J. (2005) The Chinese Approach to Capital Inflows: Patterns and Possible Explanations, IMF Working Paper 05/79, Washington DC: International Monetary Fund

Rodrik, D. and Velasco, A. (1999) Short-term Capital Flows, NBER Working Paper 7364, Cambridge, MA: National Bureau of Economic Research

Sen, S. (2005) 'China in the Bull Shop: Dealing with Finance after WTO', mimeo, New Delhi

Suryahadi, A., Sumarto, S., Suharso, Y. and Pritchett, L. (2000) 'The Evolution of Poverty in Indonesia, 1996-99', unpublished manuscript, Country Economics Department, Washington DC: World Bank

WESS (2005) Financing for Development, World Economic and Social Survey, New York: United Nations Department of Economic and Social Affairs

Zhang, L. (2005) 'China's External Imbalance: Diagnosis and Prescription', mimeo, Beijing 